\title{
ANALYSIS OF MICROFACIES AND DEPOSITIONAL ENVIRONMENT OF LIMESTONE IN YOSONEGORO AREA, GORONTALO PROVINCE, INDONESIA
}

\author{
Aang Panji Permana* Subagyo Pramumijoyo** and Akmaluddin** \\ *Department of Geological Engineering, Universitas Negeri Gorontalo, \\ Gorontalo, Indonesia \\ **Department of Geological Engineering, Universitas Gadjah Mada, \\ Yogyakarta, Indonesia
}

*Corresponding author: bagyo@ugm.ac.id

Received Date: 04 July 2019, Accepted Date: 30 October 2019, Published Date: 26 December 2019

\section{ABSTRACT}

The research location is the northern part of the Basin of Limboto Lake; the focus of the research is the limestone outcrop with 24 meter thickness in Yosonegoro area. The purpose of the study is to find out facies, standard microfacies and depositional environment on Limboto limestone. The research method carried out consisted of three methods namely the measured section, petrographic analysis and biostratigraphy analysis.

The limestone facies in the Yosonegoro area consist of two facies. Then, based on sedimentary structure, composition, color, precipitation texture, terrestrial origin components and the organism content, the two facies can divided into three different microfacies. Paleobathymetry shows a deepening from the middle shelf - upper slope to the upper slope lower slope due to the sea level rise. Compilation of standard microfacies and paleobathymetry types shows changes in depositional environment from the slope environment to the toe of slope environment. The result of this study will be led researchers to propose the name of the new formation, which is the Limboto Limestone Formation according to specific location and characteristics from the previous formation name of the Clastic Limestone Formation.

Keywords: Indonesia, Limboto, Limestone, Microfacies, Yosonegoro.

\section{INTRODUCTION}

Sulawesi Island in the territory of Indonesia has a unique form that is shaped like a $\mathrm{K}$ letter. The uniqueness of the shape of the island of Sulawesi is due to the interaction of the three large plates namely the Eurasian plate, the Australian Indian plate and the Pacific plate (Hamilton, 1979; Hutchison, 1989). Physiographically, the Sulawesi Island consists of the south arm as South Sulawesi, the middle part, the east arm as Central Sulawesi and the neck as Central and West Sulawesi, then the north arm as North Sulawesi and Gorontalo, and the southeast arm as Southeast Sulawesi (Katili, 1978; Hamilton, 1979; Sukamto and Simandjuntak, 1983; Hutchison, 1989). This background makes Sulawesi has the complex geological condition (Map 1). 
Analysis of microfacies and depositional environment

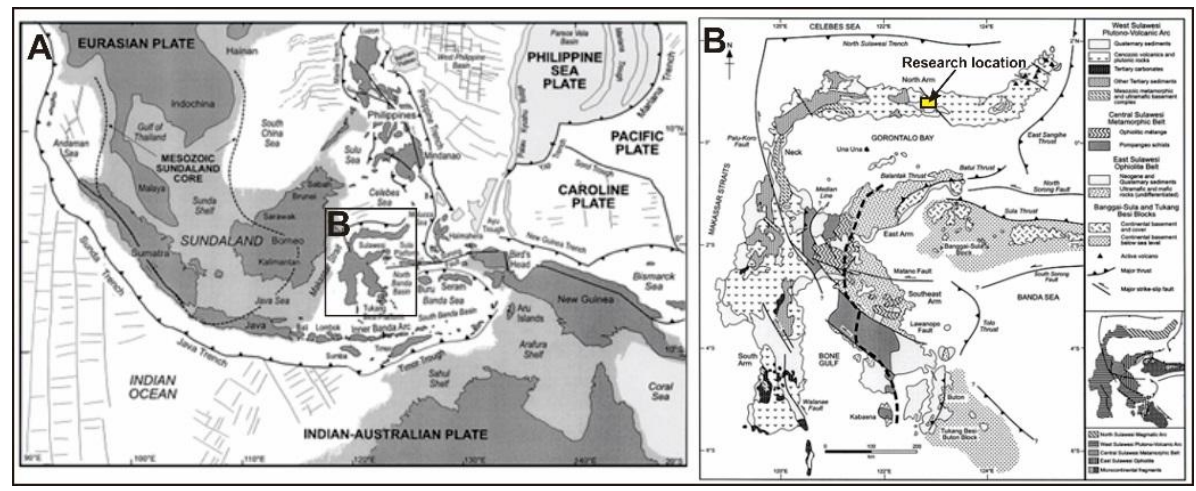

Map (1): The tectonic map of research area; (A) Tectonic map of the territory of Indonesia, (B) Tectonic map of Sulawesi island forming the letter K (Hall and Wilson, 2000).

The uniqueness also appears in the spread of limestone in the basin of Limboto Lake, which has a width about $35 \mathrm{~km}$. Its position in the middle of surrounding volcanic rocks shows its own characteristic limestone. The Basin of Limboto Lake is formed by several river valleys including Paguat, Randangan, Dumoga Ongkang, Paguyaman and, Bone. This Basin is often referred as the Limboto zone, which continues to Minahasa (van Bemmelen, 1949). Tectonic influences are very strong, especially on the position of Quartenary reef limestones in the Gorontalo region. This reefal limestone undergoes a very strong uplift, proven by field data nearby Gorontalo and the northern coast of Daka Cape, which reaches a height of more than 1,000 meters (Katili, 1970).

The study of Limestone in the Basin of Limboto Lake is still regionally conducted. Characteristics of limestone are only divided into two formations, namely Clastic Limestone Formation (TQ1) and Reef Limestone Formation (Q1). Clastic Limestone Formation (TQ1) has Pliocene-Pleistocene age, and consist of calcarenite and calcirudite are usually associated with white coral limestones. These limestones contain fossil fragments of algae and molluscs with varying thickness from 100 - 200 meters. Reef Limestone Formation (Q1) is estimated has Holocene age, which consist of the limestone with the main composition as coral fragment (Bachri et al., 1997) (Diag. 1). 
Permana et al.

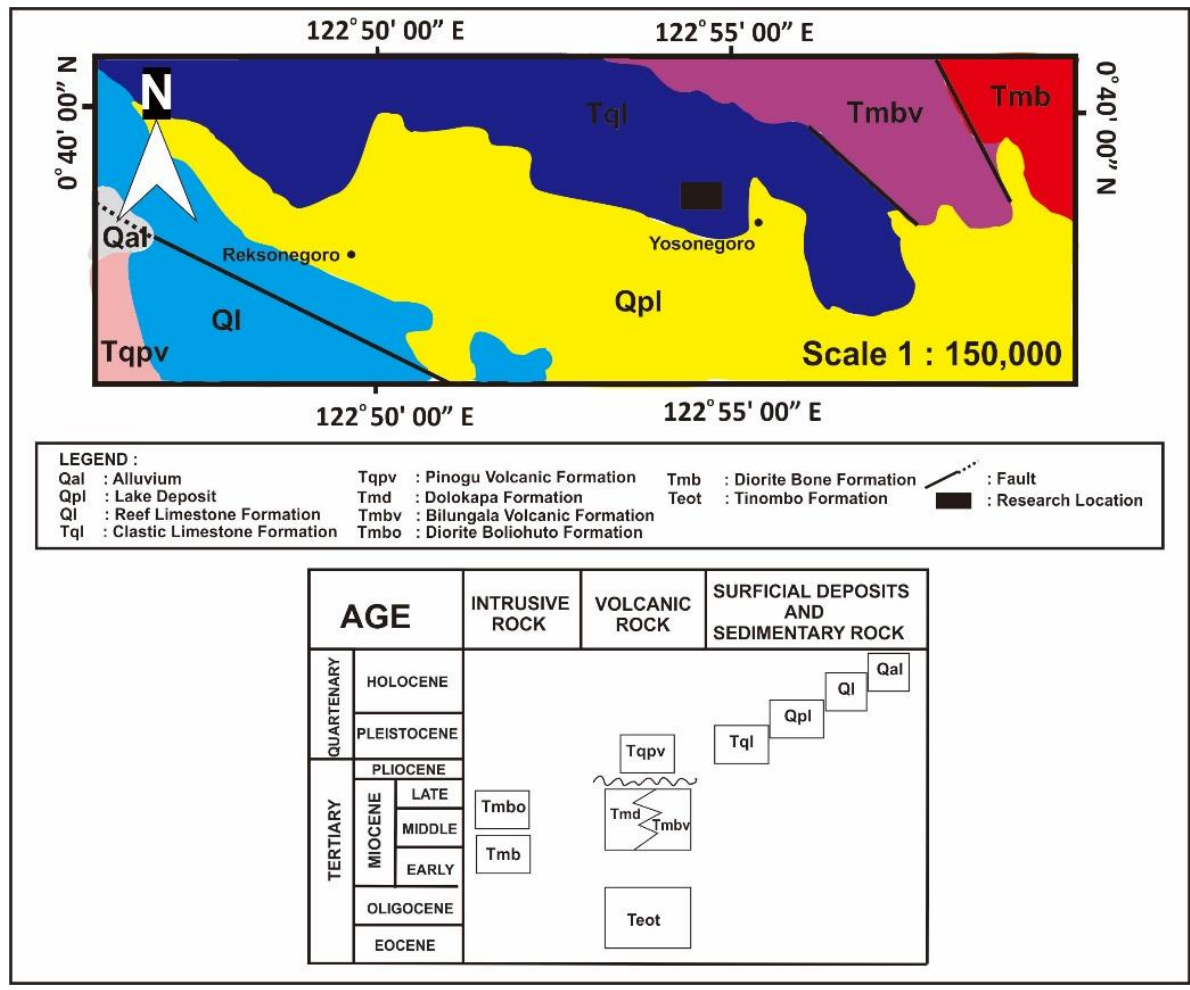

Diagram (1): Research location on Gorontalo regional geological map and Gorontalo regional stratigraphy (Bachri et al., 1994).

The limitations of detailed limestone geological data in Limboto basin encourage researchers to conduct more detailed research especially are related to facies and microfacies and depositional environment. This research is very interesting because it will produce new data and concept from Limboto Limestone. But, limited data and complex geological conditions will be a challenge in this study. Based on this background, there are three research objectives to be achieved, that is to identify the microfacies, paleobathymetry and depositional environment in the Yosonegoro area.

\section{MATERIALS AND METHODS}

The location of study in the Yosonegoro area of Gorontalo Regency is the northern part of the Basin of Limboto Lake. The geographical position is at coordinates $\left(00^{\circ} 39\right.$ ' $6.7222^{\prime \prime}$ North, $122^{\mathrm{O}} 54^{\prime} 50.0385^{\prime \prime}$ East) to $\left(00^{\mathrm{O}} 39^{\prime} 6.9397^{\prime \prime}\right.$ North, $122^{\mathrm{O}} 54^{\prime} 57.5275^{\prime \prime}$ East $)$. The research material is limestone outcrops reaching a thickness of 24 meters. Three research methods were used in this study that are measured section (MS), petrographic analysis and biostratigraphy analysis. The MS method is measuring the detail of the sedimentary layer using a jacobs staff which has a 1.5 meters interval with sequential and systematic lithology sampling (Compton, 1985; Bukhsianidze et al., 2018). The MS method is carried out to obtain the stratigraphy of the study area based on the different characteristics of each facies. Petrographic analysis using the Euromex 1053 polarization microscope. There are three 
Analysis of microfacies and depositional environment

lithologic samples analyzed by petrography. The studied limestone sample was made with a thin section using the blocking method to impregnate the blue solution into the pore to distinguish the original pore from the rock to the pore during preparation. Petrography analysis was performed to determine the type of microfacies of each facies obtained previously from the measured section method (Dickson, 1966; Crabtree et al., 1984). Then, biostratigraphy analysis was done using the Olympus SZ61 binocular microscope; it is useful to identify the type of benthic foraminifera fossil which aims to determine paleobathymetry (Jones, 1994; Nichlos, 2009; Ghosh and Sarkar, 2013; Roozpeykar and Moghaddam, 2016; Oladimeji et al., 2017).

\section{(A) Facies and Microfacies}

\section{RESULTS AND DISCUSSION}

The results of measured section at the study area indicated two limestone facies that could be distinguished from physical characteristics in texture, structure and composition (Pl. 1, Diag. 2). Facies A is coralline rudstone facies (Embry and Klovan, 1971), at the thickness of 0 - 9 meters, and has the direction of strike/dip: $\mathrm{N} 130^{\circ} \mathrm{E} / 35^{\circ} \mathrm{SW}$. This facies has brown color, grain size $<0.1-4 \mathrm{~mm}$, abundance of material with size $>2 \mathrm{~mm}$ as much as $26 \%$, grain supported packing, and poorly sorted. Based on its composition, there is skeletal fragment in the form of coral fragment, then rock fragments and quartz as non-carbonate grain. The stacking pattern of this facies is a thinning upward and thinning to the southwest. Based on coarse grain size and grain supported packing, this facies interpreted as be formed by high energy. This pattern of facies sedimentation refers to the position of relative sea level drop (Catuneanu et al., 2011) is progradation. This is influenced by larger sediment supply compared to accommodation space.

Based on petrography analysis, this facies composed of skeletal grain (19\% coral fragments, $12 \%$ red algae, $10 \%$ skeletal altered, $4 \%$ foraminifera, $4 \%$ sponge), $2 \%$ non-skeletal grain (extraclast), 2\% non-carbonate grains (iron oxide), 39\% micrite and 8\% sparit (Pl. 2A, B). Based on the containing of large bioclast from coral organisms or coral reefs as main composition, this microfacies can be classified as reef rudstone microfacies or SMF 6 (Wilson, 1975; Flugel, 2010). 


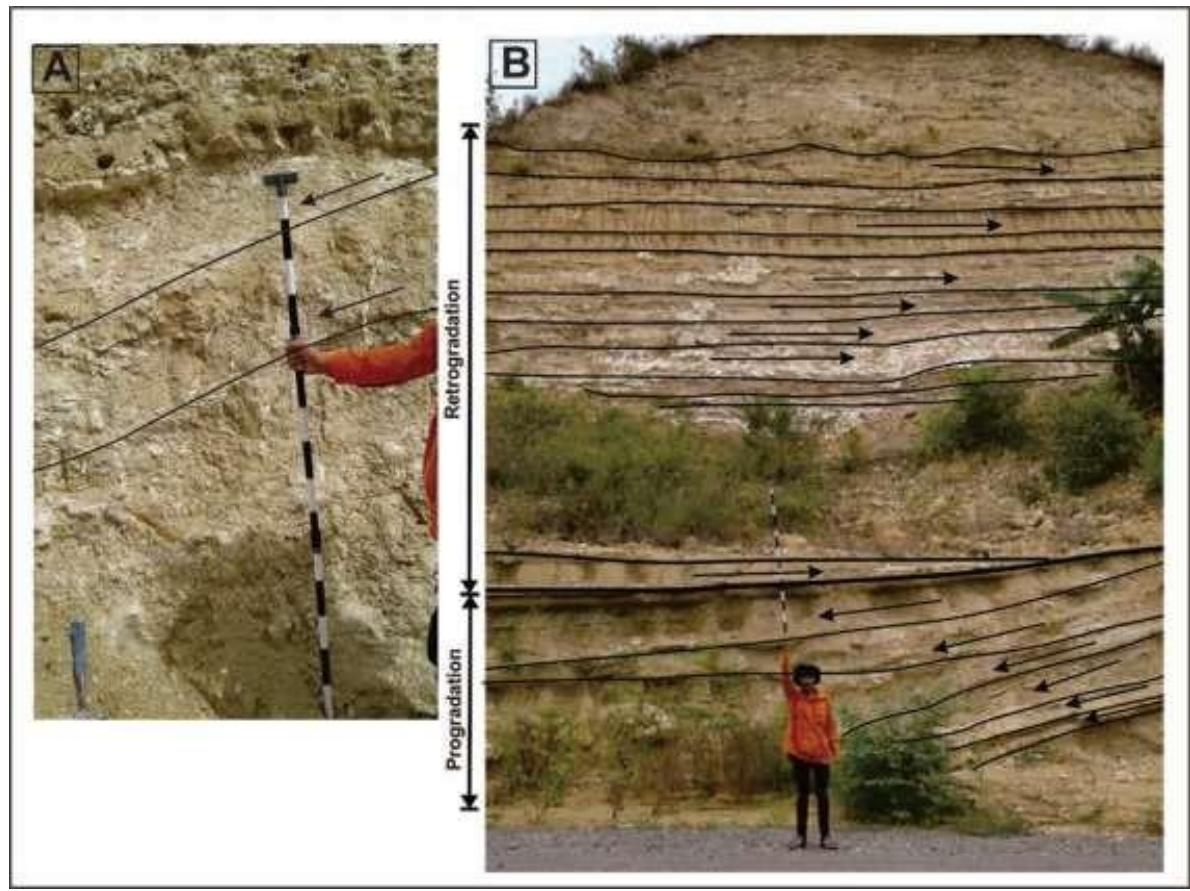

Plate (1): The sedimentation patterns of two different facies; (A) Coralline rudstone facies has a progradation sedimentation pattern, (B) Mudstone-packstone intercalation facies has sedimentation pattern initially from progradation to retrogradation.

Facies B is mudstone-packstone intercession facies (Dunham, 1962). This facies develops at the thickness of $9-24$ meters with a strike/dip direction: $\mathrm{N} 130^{\circ} \mathrm{E} / 35^{\circ} \mathrm{SW}$ at the bottom then changes to the strike/dip direction: $\mathrm{N} 130^{\circ} \mathrm{E} / 10^{\circ} \mathrm{SW}$. The mudstone has yellowish brown colour, fine grain size $<0.1 \mathrm{~mm}$, mud supported packing, and well sorted. Based on its composition, there is no allochem in this sample, and only found quartz mineral as a fragment $(5 \%)$. Micrite is very dominant as matrix with abundant of $95 \%$ (Pl. 2C, D). The stacking pattern of this facies is thickening upward and thinning to the southwest.

The packstone has light brown colour, coarse grain size $<2 \mathrm{~mm}$, poorly sorted and closed fabric. Based on its composition, there are coral and quartz mineral as fragments in this sample. This facies has thinning upward stacking pattern and scouring structure at the upper limit of contact with mudstone. Petrography analysis showed for the packstone composed of $4 \%$ large benthic foraminifera, $10 \%$ peloid, $2 \%$ extraclast, $12 \%$ quartz as non-carbonate grain, with $68 \%$ micrite and $4 \%$ sparite as a matrix. Some porosity was found in this sample such as interparticle and vuggy porosity with an abundance of $21 \%$ (Pl. 2E, F).

Based on the grain size that develop tend to be finer, it is interpreted this facies are formed at a lower energy than the previous facies. The stacking pattern is initially progradation then develops the retrogradation (backstapping occurs) above due to relative sea level rise, which showed the sediment supply is lower than accommodation space. Changes in sedimentation 


\section{Analysis of microfacies and depositional environment}

patterns are supported by changes in the magnitude of the slope of the coating which was initially $35^{\circ}$ to be gentler $10^{\circ}$.

Based on the texture and composition, this facies can be classified into types of pelagic mudstone microfacies (SMF 3) and packstone litho-bioclastics microfacies (SMF 4) (Wilson, 1975; Flugel, 2010). The reason is based on the main constituent component of mudstone is micrite which becomes a finer-sized matrix that is formed, so it is appropriate to be included in SMF 3. Whereas the packstone, has composition of the granules shows strong original sources such as quartz and allochem consisting of large foraminifera, extraclast and peloid, so it is appropriate to be included in SMF 4.
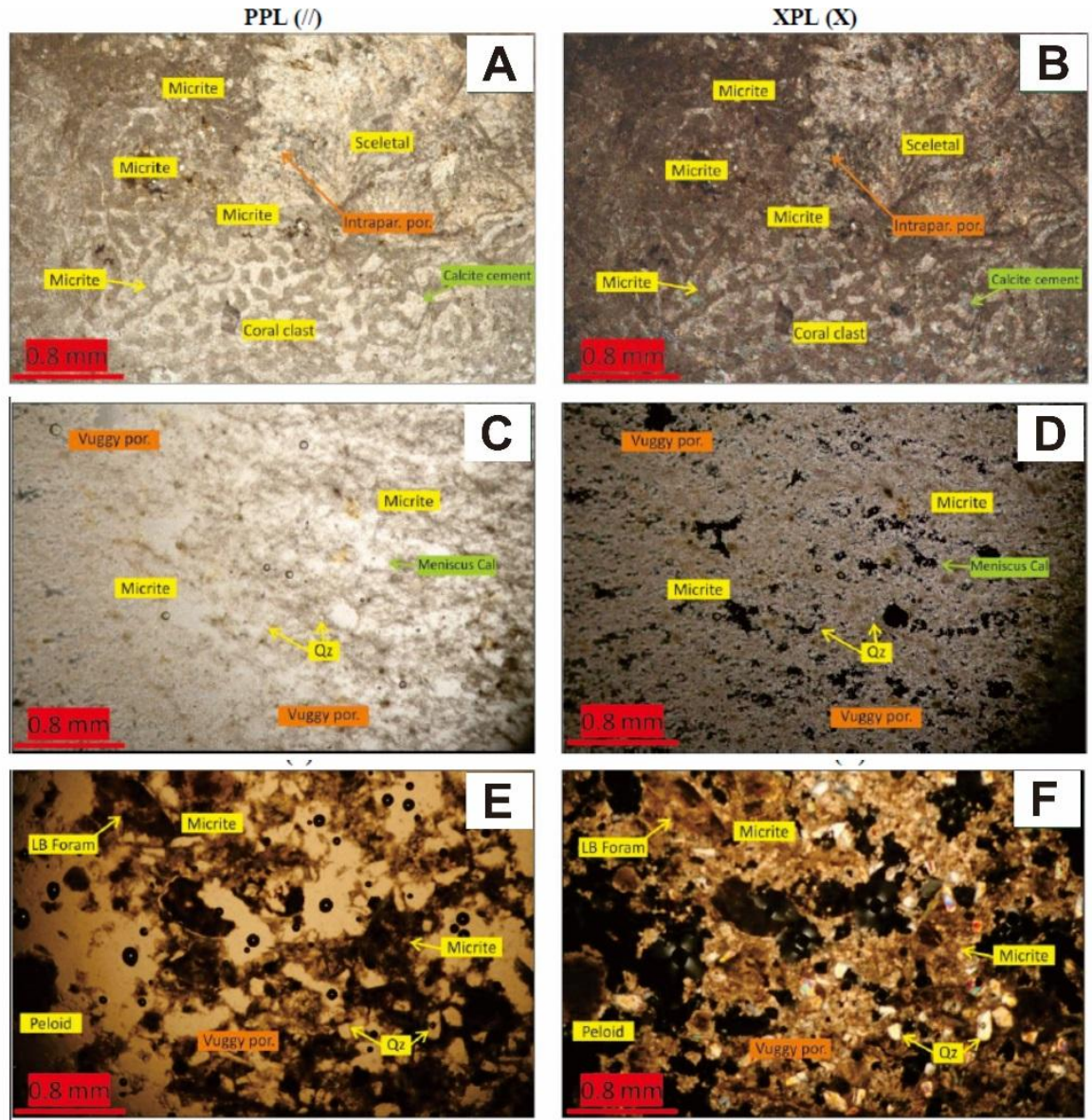

Plate (2): Petrography analysis for three samples of thin section, parallel nicol (left) and cross nicol (right); (A, B) coralline rudstone, $(\mathrm{C}, \mathrm{D})$ Mudstone, $(\mathrm{E}, \mathrm{F})$ packstone.

\section{(B) Paleobathymetry}

Paleobathymetry becomes important data to support the identification of the depositional environments; paleobathymetry can be known from biostratigraphy analysis, especially a 


\section{Permana et al.}

collection of benthic fossils, with a total of three samples analyzed. Benthic fossils in the reef rudstone microfacies represented in 3B sample consisted of Cornuspira foliacea (Philippi), Fijinonion fijiense (Cushman and Edwards), Melonis affinis (Reuss), Nonion fabum (Fichtel and Moll) and Rhabdammina discreata (Brady). The interpretation of the presence of five types of benthic fossils shows paleobathymetry in the middle shelf to upper slope zone at a depth of 73.2 - 283.65 meters (Tipsword et al., 1966; Jones, 1994).

The benthic fossils in the pelagic mudstone microfacies - microbreccia microfacies represented by 3E, 3G, 3H, 3I and 3J samples consisted of Fijinonion fijiense (Cushman and Edwards), Gyrodinoides soldanii (d'Orbigny), Nonion fabum (Fichtel \& Moll), Praeglobobulimina ovata (d'Orbigny), Rhabdammina discreata (Brady) and Saccorhiza ramosa (Brady). The interpretation of the presence of these six types of benthic fossils shows the paleobathimetric changes. Sequentially $3 \mathrm{E}$ sample paleobathymetry in the outer shelf upper slope zone with a depth of 183-366 meters, 3G sample in the upper slope zone with a depth of 283.65-366 meters, $3 \mathrm{H}$ sample in the upper slope - lower slope zone with a depth of 283.65-1,830 meters, 3I sample in the upper slope - lower slope zone with a depth of 283.651,830 meters, and $3 \mathrm{~J}$ sample paleobathymetry in the upper slope zone with a depth of 283.65 466.65 meters (Tipsword et al., 1966; Jones, 1994). The sequence of paleobathimetric changes from bottom to top can be seen in Diagram (2). 
Analysis of microfacies and depositional environment

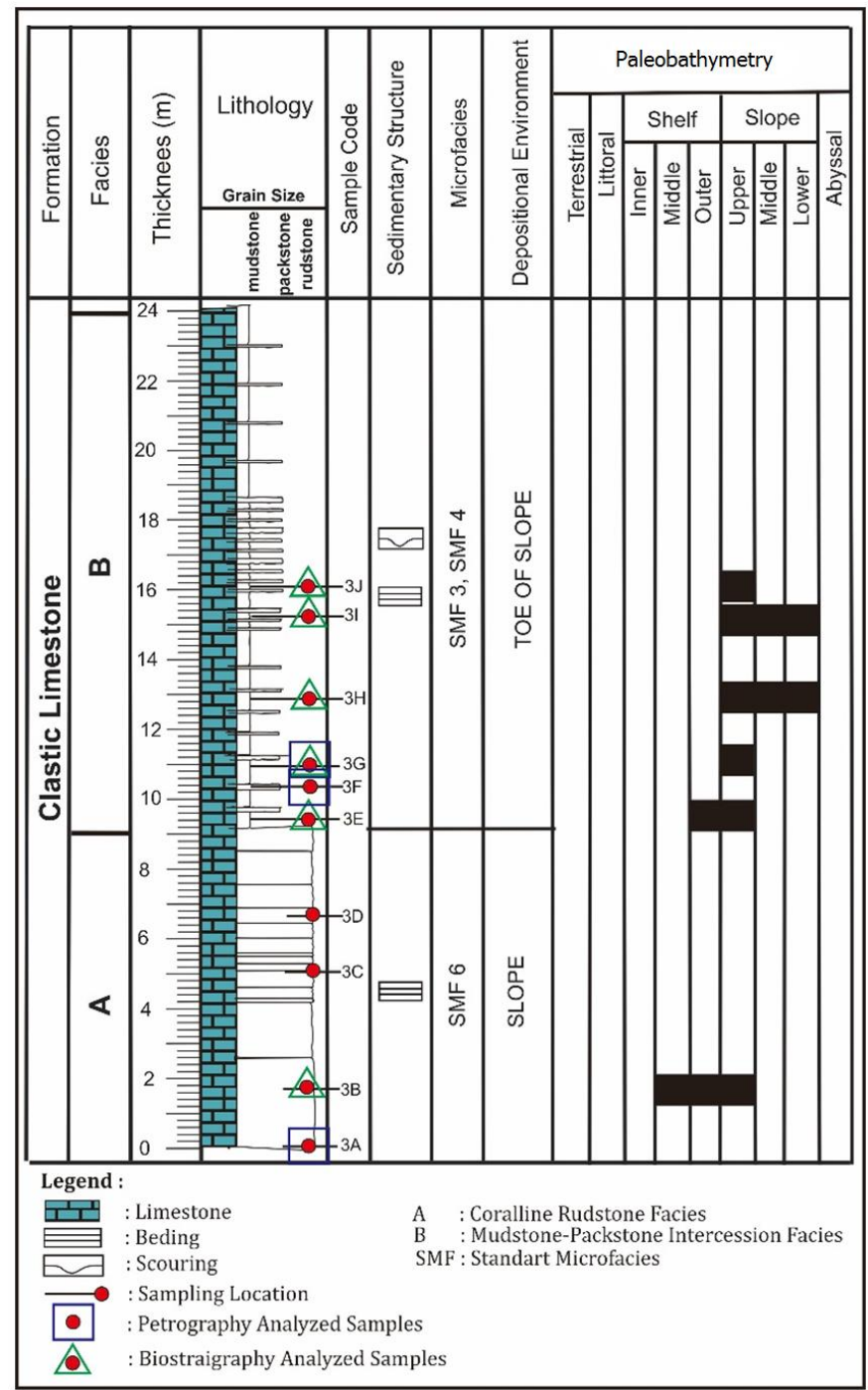

Diagram (2): Chart of facies distribution, standard microfacies, depositional environment and paleobathymetry in study area.

\section{(C) Depositional Environment}

The depositional environment interpretation or facies zone (FZ) of the study area was determined from the compilation of SMF type and paleobathymetry identification using classification Wilson (1975) and Flugel (2010). Depositional environment for reef rudstone microfacies (SMF 6) with paleobathymetry middle shelf - upper slope is a slope environment (FZ4). 


\section{Permana et al.}

Depositional environment of pelagic mudstone microfacies (SMF 3) and packstone lithobioclastics microfacies (SMF 4) with paleobathymetry upper slope - lower slope is a toe of slope environment (FZ 3). The history of settling in the study area was preceded by sedimentation of reef rudstone microfacies in the slope area and then deposited in lower energy a pelagic mudstone microfacies and packstone litho-bioclasctics microfacies in the toe of slope environment (Diag. 3).

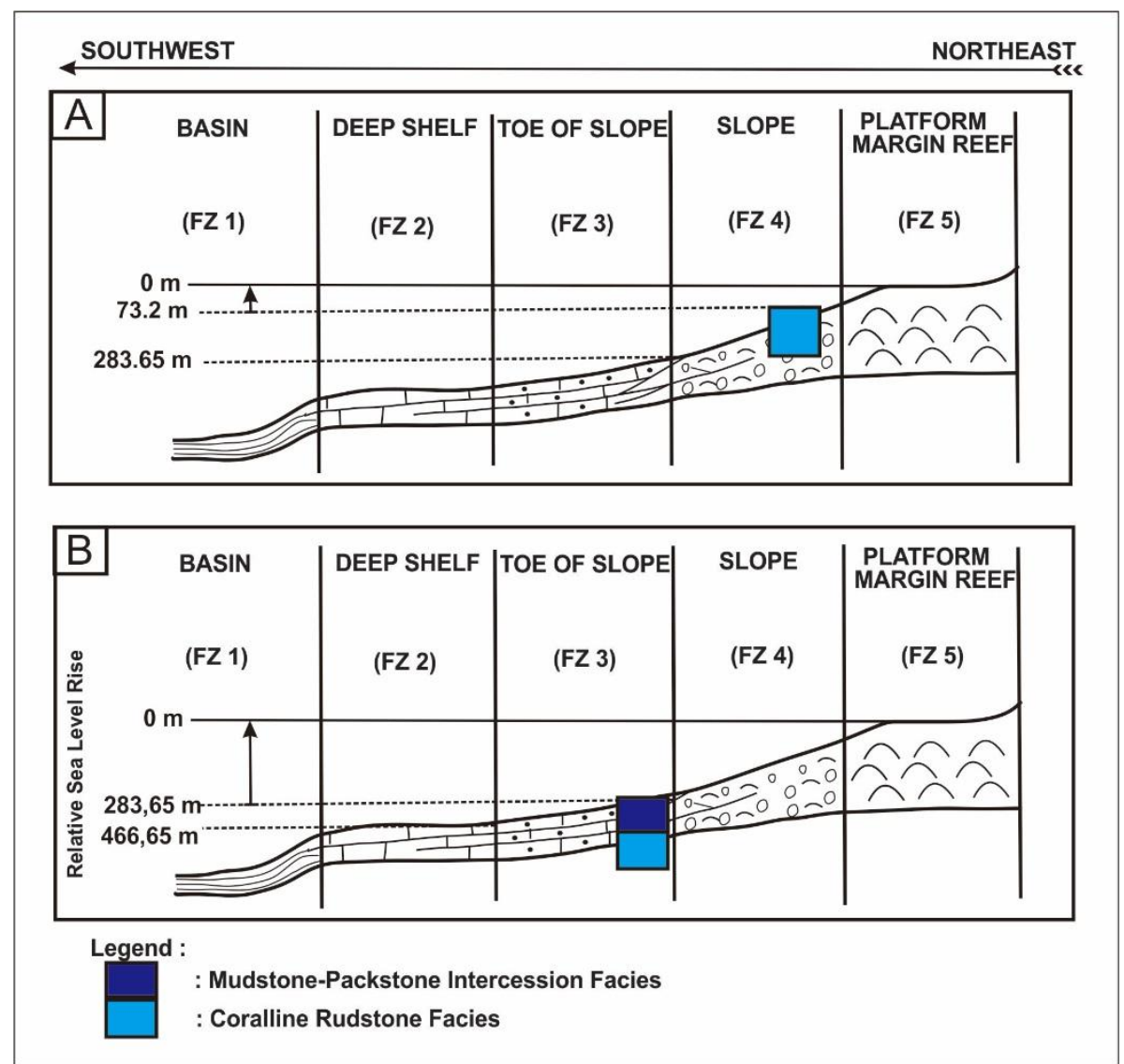

Diagram (3): Changes in the depositional environment from changes in relative sea level rise; (A) Initially deposited by coralline rudstone facies at a depth of 73.2283.65 meters in the slope area (FZ 4), (B) A change in relative sea level that was deepened and deposited by mudstone-packstone intercession facies at a depth of 283.65-466.65 meters in the toe of slope area (FZ 3). (Modified Wilson, 1975; Flugel, 2010).

\section{CONCLUSIONS}

Limestone formation in the Yosonegoro area comprises two facies and three microfacies. Paleobathymetry shows an increasingly deep change due to the sea level rise from the middle shelf -upper slope to the upper slope - lower slope. Compilation of standard microfacies type 
Analysis of microfacies and depositional environment

and paleobathymetry shows changes in depositional environment. Initially deposited reef rudstone microfacies in the slope environment (FZ 4) and then deposited in harmony with pelagic mudstone microfacies and packstone litho-bioclastics microfacies in the toe of slope environment (FZ 3). The results of this study became a discourse to propose the name of a new formation according to the location and characteristics of limestone based on facies, microfacies and depositional environment. The name of the new formation proposed is the Limboto Limestone Formation from the name of the previous formation namely the Clastic Limestone Formation.

\section{LITERATURE CITED}

Bachri, S., Ratman, N, and Sukido. 1994. Geological map of the tilamuta sheet, sclae 1:250,000. Geological Research and Development Centre, Bandung. (Indonesia version).

Bachri, S., Partoyo, E., Bawono, S. S., Sukarna, D., Surono and Supandjono, J. B. 1997. Geology of Gorontalo, North Sulawesi. Collection of Research Papers and Mapping of the Center for Geological Research and Development 1996/1997, p 18-30. (Indonesia version).

Bukhsianidze, M., Chagelishvili, R. and Lordkipanidze, D. 2018. Late Miocene vertebrate site of Chachuna Iori valley, Georgia, Southern Caucasus. Bulletin of the Georgian National Academy of Sciences, 12(2): 70-75.

Catuneanu, O., Galloway, W. E., Kendall, C. G. S. C., Miall, A. D., Posmentier, H. W., Strasser, A. and Tucker, M. E. 2011. Sequence stratigraphy: methodology and nomenclature. Newsletters on Stratigraphy, 44(3): 173-245.

Compton, R. R. 1985. Geology in the field. New York, Wiley Press, 416 pp.

Crabtree, S. J., Ehrlig, R. and Prince, C. 1984. Evaluation of strategies for segmentation of blue-dyed pores in thin sections of reservoir rocks. Computer Vision, Graphics and Image Processing, 28: 1-18.

Dickson, J. A. D. 1966. Carbonate identification and genesis revealed by staning. Sedimentary Petrology Journal, 36(2): 491-505.

Dunham, R. J. 1962. Classification of carbonate Rocks according to depositional texture. In: Ham, W. E. (Ed.), Classification of carbonate Rocks: American Association of Petroleum Geologists Memoir, p 108-121.

Embry, A. F. and Klovan, J. E. 1971. A late Devonian reef tract on northeastern Banks Island, Northwest Territories. Bulletin of Canadian Petroleum Geology, 19: 730-781.

Flugel, E. 2010. Microfacies of carbonate rocks: Analysis, interpretation and application. Second edition, Springer-Verlag Berlin Heidelberg, XXIII, 984 pp. 


\section{Permana et al.}

Ghosh, A. K. and Sarkar, S. 2013. Facies analysis and paleoenvironmental interpretation of Piacenzian carbonate deposits from the Guitar Formation of Car Nicobar Island, India. Geoscience Frontiers, (4): 755-764.

Hall, R. and Wilson, M. E. J. 2000. Neogene sutures in eastern Indonesia. Journal of Asian Earth Sciences, 18: 787-814.

Hamilton, W. 1979. Tectonics of the Indonesian region. US Geological Survey professional paper, 1078, $345 \mathrm{pp}$.

Hutchison, C. S. 1989. Geological evolution of Southeast Asia. Oxford Monographs on Geology and Geophysics no. 13. Oxford: Clarendon Press, xv +368 pp.

Jones, R. W. 1994. The challenger foraminifera. Oxford University Press, 149 pp.

Katili, J. A. 1970. Large transcurrent faults in Southeast Asia with special reference to Indonesia. International Journal of earth Science, 59(2): 581-600.

Katili, J. A. 1978. Past and present geotectonic position of Sulawesi, Indonesia. Tectonophysics, 45: 289-322.

Nichlos, G. 2009. Sedimentology and stratigraphy. Blackwell Science Ltd., London, 335 pp.

Oladimeji, A., Adeyinka, S. A., Adekeye, O. A., Olusegun, O. and Emmanuel, O. F. 2017. Foraminifera biostratrigraphy and depositional environment of sediment in Sile- Well offshore Dahomey Basin Benin Republic. MAYFEB Journal of Environmental Science, 1: 18-33.

Roozpeykar, A. and Moghaddam, I. M. 2016. Benthic foraminifera as biostratigrpahical and paleoecological indicators: an example from Oligo-Miocene deposits in the SW of Zagros Basin, Iran. Geoscience Frontiers, 7: 125-140.

Sukamto, R., and Simandjuntak, T. O. 1983. Tectonic relationship between geologic provinces of Western Sulawesi, Eastern Sulawesi and Banggai-Sula in the light of sedimentological aspects. Bulletin of the Geological Research and Development Centre, 7: 1-12.

Tipsword, H. L., Setzer, F .M. and Smith, L. F. 1966. Interpretation of depositional environment in gulf coast petroleum exploration from paleoecology and related stratigraphy. Gulf Coast Association of Geological Societies, 16: 119-129.

van Bemmelen, R. W. 1949. The geology of Indonesia: Vol. IA - General geology of Indonesia and adjacent archipelagoes. Government Printing House, The Hague, 372 pp.

Wilson, J. L. 1975. Carbonate facies in geologic history. Springer Verlag, New York, 471p. Available at: https://doi.org/10.1007/978-1-4612-6383-8 


\author{
تحليل السحنات الدقيقة والبيئة الترسيبية لصخور اللايمستون في يوسونيكورو، \\ آنج بانجي بيرمانا *، سباجيو براميوميجويا**و اكمل الدين** \\ * قسم الجيولوجي الهندسية، جامعة نيجري كورونتالو، كورونتالو، اندونوسيا \\ ** قسم الجيولوجي الهندسية، جامعة جادا مادا، يوجي اكارتا، اندونوسيا

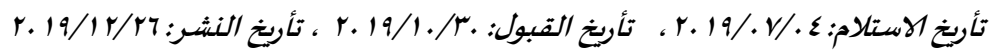

\title{
الخلاصة
}

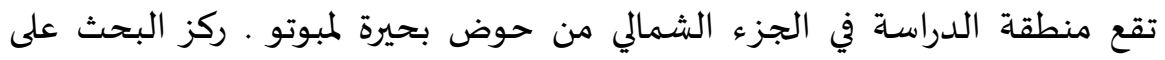
مكاشف صخور اللايمستون الذي يبلغ سمكه ع؟ متر ، في منطقة يوسونيكورو . وتهدف الدراسة الى ايجاد السحنات، والسحنات الدقيقة القياسية وبيئة الترسيب. تتكون طريقة البحث من ثلاث طرق هي:- دراسة المقطع، وتحليل الصخارية، وتحليل الطباقية الحياتية. تتكون سحنات اللايمستون في منطقة يوسونيكورو من سحنتين. اعتمادأ على التراكيب الرسوبية، والمكونات، واللون، والنسيج، ومصدر المكونات الارضية، والمحتوى

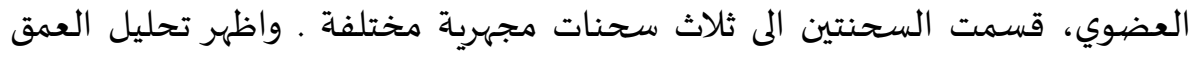

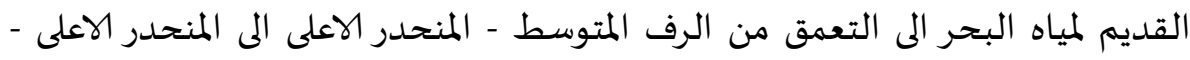

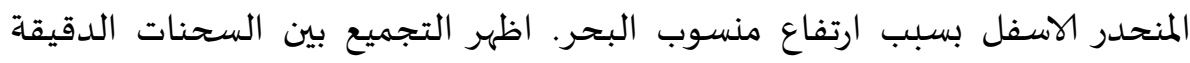

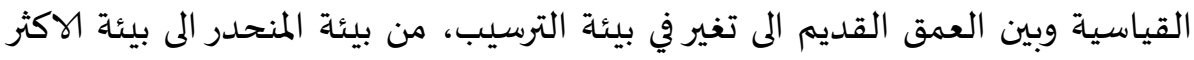

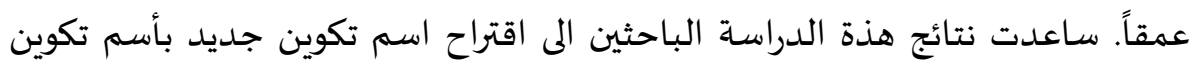

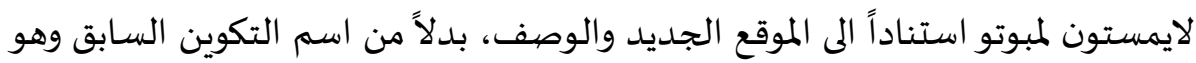
تكوين اللايمستون الفتاتي . 